\title{
COMPARATIVE ANALYSIS OF METHODS FOR DETERMINATION OF SUPPLY FLOWS
}

\author{
Semchenko N. O. ${ }^{1}$, Kholodova O. O. ${ }^{1}$, Buhaiova M. O. ${ }^{1}$ \\ ${ }^{1}$ Kharkov National Automobile and Highway University
}

\begin{abstract}
Problem. The capacity of signalized intersections is determined using the concept of "saturation flow". It is the main characteristic in the process of their analysis, design and calculation. The work is devoted to solving the scientific-applied problem of increasing the efficiency of the signalized intersection at one level by choosing a rational method of determining saturation flows for these characteristics of traffic flows, geometric parameters of the intersection and infrastructure in its area. The subject of the study is the influence of the main characteristics of the traffic flow, parameters and infrastructure of the intersection on the saturation flow value. Goal. The aim of the work is the analysis of the influence of the main characteristics of the traffic flow, parameters and infrastructure of the intersection on the saturation flow value. Methodology. The calculation of the control regime at the intersection is based on determining the relation between the traffic intensity of vehicles at the intersection and the saturation flow value, which changes under the influence of a number of factors. Analytical calculation of the saturation flow value is based on using of correction factors that take into account the influence of these factors. Results. The methods of determination of saturation flows are analyzed out in the work; performed a comparative analysis of the definition of ideal saturation flows by different methods; a comparative analysis of the determination of the saturation flow correction coefficients for the parameters that have an effect on it were performed; the estimation of discrepancy at calculations of coefficients of correction of saturation flows by various methods is done; the list of coefficients which need to be considered at definition of their influence on a saturation flow is refined. Originality. In oppose to classical and other approaches to determining the saturation flow, the method recommended by the American "Highway Capacity Manual" takes into account more parameters of influence. It is proposed to use this method for the saturation flow calculation, but with an updated list of coefficients that must be taken into account in the calculations. Practical value. The results of the work can be used in the practice of improving the efficiency of signalized intersections in sections of the urban road network, as well as in further research on this topic.
\end{abstract}

Key words: saturation flow; signalized intersection; urban road network; method.

\section{Introduction}

The growth of the vehicle fleet and the volume of transportation increases traffic intensity. All this in urban areas leads to increased negative impact of motorization. It is especially acute at the nodal points of the urban road network at the at-grade intersection. Here traffic delays increase, queues and congestion are formed, which causes a decrease in speed, unjustified overconsumption of fuel, increased wear of components and vehicles, pollution of the city air basin by products of incomplete fuel combustion.

Improvement of the effectiveness of the urban road network in the existing architectural and planning scheme of cities requires using of the organizational measures set. At the at-grade intersections these include, primarily, the introduction of signalized. During implementation of the set of traffic signals facility, the main task facing specialists is to ensure maximum capacity of the intersections, minimizing delays and queues at a high level of traffic safety.

The relevance of the topic is determined by the need to develop a method for calculating cycles, capacity and delays at the signalized intersections.

\section{Analysis of publications}

The capacity of the signalized intersections is determined by using the concept of "saturation flow" - the main characteristic in the process of analysis, design and calculation of signalized intersections.

The classical interpretation defines the saturation flow as the maximum intensity queue discharge at a fully saturated phase $[1,2]$. That means that it is a flow with a constant in- 
tensity, which occurs when vehicles move at the minimum possible intervals. However, the use of saturation flow values in the following interpretation when calculating, for example, the capacity per lane by the formula:

$$
c_{i j}=\frac{S_{i j} G_{\mathrm{ej}}}{C},
$$

where $c_{i j}$ - capacity per lane $i$ of the signalized phase $j$, veh/h;

$S_{i j}$-saturation flow rate for per lane $i$ of the signalized phase $j$, veh/h;

$G_{\text {ej }}$ - effective length of the signalized phase $j$, s;

$$
C \text { - cycle length, } \mathrm{s} \text {, }
$$

leads to overestimated values of capacity, because the constant traffic intensity with minimal intervals occurs after after turning on the traffic signal, which allows traffic, $3-4$ cars will pass $[1,2]$.

Therefore, some researchers believe that the saturation flow should be interpreted as the average intensity of the departure of vehicles from the stop line during the green signal burning time, when a sufficiently the high queue of cars discharge. According to Yu. A. Vrubel [3] "... such a definition of the saturation flow is close to the concept of capacity during the green signal burning time" and takes into account both the lost time and the green signal duration.

Analysis of research works of domestic and foreign researchers showed that each author formulates a different definition of the saturation flow.

So, Yu. A. Kremenets [1] defines the saturation flow as the maximum intensity of the vehicles queue discharge during the saturated signalized phase.

Yu. A. Vrubel [3] defines the saturation flow as the average intensity of a discharge sufficiently long queue of vehicles through the stop line during the action of the permitting signal.

F. V. Webster and B. M. Cobbe, D. Branston and H. J. Van Zulien, R. W. Stokes [4-6] consider the saturation flow as a constant intensity of the queue discharge of considerable length.

J. G. Wardrop [7] understood the saturation flow as a state of traffic flow that occurs when vehicles overcome the stop line with the minimum possible intervals during movement.

The basic "Webster's model", presented by FV Webster in his work in 1958 "Traffic Signal Settings" [8], was later used by many scientists: A. Miller, A. Clayton, J. Wardrop, B. Cobbe, B. Greenshields.
In the "Webster's model" the approach to saturation flow is called a uniform rate of departure. With a saturated flow of vehicles, the capacity is proportional to the effective duration of the green signal.

F. V. Webster and B. M. Cobbe [4] refer to the dependence:

$$
G_{e}=G+Y-L,
$$

where $G$ - the actual duration of the green signal, s;

$Y$ - duration of the amber signal, s;

$L$ - effective duration of the green signal ("lost time"), s.

The "lost time" $L$ can be divided into two components: the duration of vehicle delays at the start of the queue at the beginning of the green signal; duration of vehicle delays due to not fully used yellow signal period. These components of D. Branston, H. J. Van Zuylen [5] are called, respectively: the initial green delay $L_{C}$; final green delay $L_{Y}$ - and they are used to determine the "lost time":

$$
L=L_{C}+Y-L_{Y}
$$

and the effective duration of the green signal:

$$
G_{e}=G+L_{Y}-L_{C}
$$

Based on the above, the saturation flow can be defined as the maximum intensity $N_{a}$ for the duration of the permitting signal. Taking into account the feedback between the saturation flow and the average duration queue discharge, the direct analysis approach is used to determine the maximum capacity of the signalized intersections (1).

If the flow of vehicles arriving on the approach is denoted as $q$, then to ensure adequate approach capacity, the inequality must be observed:

$$
\mathrm{S}\left(G_{e} / C\right) \geq q .
$$

Inequality (5) means that the capacity of the approach must be greater than or equal to the demand for it. However, if inequality (5) is transformed, then to provide the required capacity on the approach to the intersection, the effective duration of the green signal must be such that the following condition is met:

$$
\left(G_{e} / C\right) \geq q / S .
$$


Therefore, when analyzing the efficiency of the control cycle, the saturation flow is used as the main value.

According to research conducted in Washington [9], the theoretical limit for signalized intersections is the value of 2000 cars per hour passing at a green traffic signal. In practice, this value varies from 1500 to $1800 \mathrm{veh} / \mathrm{h}$ and is commonly used for planning and design purposes.

In the work of B. D. Greenshields, D. Schapiro, and E. L. Ericksen [10] to determine the saturation flow considered the duration of the movement with an interval and the turnon delay of the permitting signal and its change to prohibitory. It was found that the first car enters the intersection in $3.8 \mathrm{~s}$ after turning on the green signal, and that following cars start driving in $3.1 ; 2.7$ and $2.2 \mathrm{~s}$ after the previous vehicle. All following cars after the fifth, drove to the intersection with an average interval $2.1 \mathrm{~s}$. The studied process of motion corresponds to the value of the saturation flow in $1714 \mathrm{veh} / \mathrm{h}$.

In the Highway Capacity Manual [9], the "base flow" was set at $1500 \mathrm{veh} / \mathrm{h}$ on a $12 \mathrm{ft}$ lane $(3.66 \mathrm{~m})$ per hour of the permitting signal or $1250 \mathrm{veh} / \mathrm{h}$ on a $10 \mathrm{ft}$ lane $(3.03 \mathrm{~m})$. These basic values are converted to continuous traffic flows entering the signalized intersection with an interval of $2.4 \mathrm{~s}$ for lanes with a width of $3.66 \mathrm{~m}$ and $2.9 \mathrm{~s}$ for lanes with a width of $3.03 \mathrm{~m}$.

R. M. Bartle, V. Skoro and D. L. Gerlough [11], following a procedure similar to that used in [10], investigated initial delays and intervals of queue discharge at 13 signalized intersections in Los Angeles. The average time interval for all lanes on the studied approaches varied from 0.95 to $1.63 \mathrm{~s}$, the saturation flow was $2208 \mathrm{veh} / \mathrm{h}$.

D. G. Capelle and C. Pinnell [12] in their studies found out that all cars moving with average interval $2.1 \mathrm{~s}$ immediately after the second car drove, their value of the saturation flow was $1714 \mathrm{veh} / \mathrm{h}$.

W. E. Assmus [13], studied signalized intersections with two specially designated lanes for turning left and defined the average interval as the time between the third and last vehicle in the queue. The saturation flow obtained by him varied from $1540 \mathrm{veh} / \mathrm{h}$ up to $1600 \mathrm{veh} / \mathrm{h}$ depending on the type of movement.

R. L. Carstens [14] measured the movement interval for the fifth and following vehicle on average $2.3 \mathrm{~s}$ and obtained a saturation flow value $1572 \mathrm{veh} / \mathrm{h}$.

D. J. Berry [15] measured the saturation flow at 16 suburban intersections and obtained different values depending on the type of traffic (straight, left turn) and lane width $(9 \mathrm{ft}$ and above), thereby revealing the pattern of change of the studied lane from these parameters.

In the work of G. F. King and M. Wilkinson [16] the study was conductes about the relationship between the designed signal and the intervals of queue discharge at 39 signalized intersections. After processing the data, the value of the saturation flow $1636 \mathrm{veh} / \mathrm{h}$ was obtained.

W. Kunzman [17] studied signalized intersections in Orange County, California and determined the dependence of the interval of movement on the number of vehicles waiting for the permitting signal. During the study, depending on the length of the queue, the values of the saturation flow $1597-1672 \mathrm{veh} / \mathrm{h}$ were obtained for direct and 1494-1632 veh/h for left turning traffic, respectively.

In the case where the saturation flow cannot be determined by field study, the "ideal saturation flow" value is used with the application of correction factors that change the "ideal" value under certain conditions. In the Interim Materials on Highway Capacity [18], the saturation flow is defined as "ideal" and it is used in combination with correction factors that take into account the influence of those factors: adjustment factor for lane width; adjustment factor for approach grade; adjustment factor for heavy vehicles in traffic flow; adjustment factor for existence of a parking lane and parking activity adjacent to lane group; adjustment factor for blocking effect of local buses that stop within intersection area; adjustment factor for area type; adjustment factor uneven loading of a group of lanes; adjustment factor for left turns in lane group; adjustment factor for right turns in lane group [19].

The average calculated values for ideal conditions when the section has no grade, the impact of heavy vehicles, buses and parked cars is absent or minimal, and the right and left turns are unobstructed, are in the American manual for assessing the capacity of signalized intersections [20] $1900 \mathrm{veh} / \mathrm{h}$, in German $2000 \mathrm{veh} / \mathrm{h}$ [21].

In the research of A. G. Levashov [19] the value of the "ideal saturation flow" is 1904 $\mathrm{veh} / \mathrm{h}$.

Y.A. Kremenets, M.P. Pechersky, M.B. Afanasyev [22] for the case of movement in the forward direction on the road without grade, the saturation flow is calculated by the formula that relates this indicator to the roadway width:

$$
S=525 \cdot W_{r}
$$


where $S$ - saturation flow rate, veh/h; $W_{r}$ - lane width, $\mathrm{m}$.

Formula (7) is applicable when $5.4 \mathrm{~m} \leq \mathrm{B} \leq$ $18.0 \mathrm{~m}$. If the width of the roadway is less than $5.4 \mathrm{~m}$, it is possible to use the data from table 1 [22] or 2 [23]. Missing values in the table can be found by interpolation.

Table 1 - The value of the saturation flow depending on the width of the approach according to Yu. A. Kremenets [22]

\begin{tabular}{|l|l|l|l|l|l|l|}
\hline$S, \mathrm{veh} / \mathrm{h}$ & 1850 & 1875 & 1950 & 2075 & 2475 & 2700 \\
\hline$W_{r}, \mathrm{~m}$ & 3.0 & 3.3 & 3.6 & 4.2 & 4.8 & 5.1 \\
\hline
\end{tabular}

Table 2 - The value of the ideal saturation flows of the lane according to E. M. Lobanov [23]

\begin{tabular}{|l|c|c|c|c|c|}
\hline$W_{r}, \mathrm{M}$ & 3.0 & 3.5 & 4.0 & 4.5 & 5 \\
\hline$S_{0}$, veh/h & 1800 & 1900 & 2100 & 2300 & 2600 \\
\hline
\end{tabular}

Thus, a literature review about the saturation flow studies showed a variety of methods and approaches that are used to determine it.

Analysis of different methods of determining the saturation flow indicates the ambiguity of determining the saturation flow and gives different final results, which fluctuate in a fairly wide range from $1572 \mathrm{veh} / \mathrm{h}$ up to $2000 \mathrm{veh} / \mathrm{h}$. The lack of a single method of calculation of the considered value can lead to an erroneous result when we are evaluating the efficiency of the cycle duration or developing a new one.

In our opinion, it is necessary to use the average values of the saturation flow when analyzing the parameters of the signalized intersection and the calculations of the control modes.

The saturation flow depends on many factors: the width of the roadway (lane); approach grade on the intersection; condition of the road surface; visibility of the intersection by the driver; the presence of pedestrians and standing cars in the intersection area, etc. Therefore, for each approach to the intersection it must be determined separately.

\section{The purpose and the statement of the problem}

The aim of the work is to increase the efficiency of the signalized at-grade intersection by choosing a rational method of determining saturation flows for these characteristics of traffic flows, geometric parameters of the intersection and infrastructure in its area.

To achieve this goal, it is necessary to solve the following tasks:

- to investigate the methods of determining saturation flows;
- accomplish a comparative analysis of the determination of ideal saturation flows by different methods;

- accomplish a comparative analysis of the determination of the saturation flow correction coefficients for those parameters that affect it;

- estimate the deviation in the calculation of saturation flow correction coefficients by different methods.

\section{Methods for determining the saturation flow on the approach to the intersection}

Analysis of the values of ideal saturation flows allows us to draw the following conclusions:

- the values of the ideal saturation flow determined in recent years are higher than in the middle of the last century. This is due to the much better dynamic characteristics of vehicles;

- the values of the ideal saturation flow significantly depend on the lane width;

- the value of the ideal saturation flow per lane with a width of $3.6-3.75 \mathrm{~m}$ should be taken $1900 \mathrm{veh} / \mathrm{h}$.

The real saturation flow on the intersection approach, in contrast to the ideal, is limited by a significant number of factors. In the general case, the theoretical saturation flow is determined by the formula:

$$
S=S_{0} \cdot \prod f_{i}
$$

where $S$ - real saturation flow rate for subject lane group, expressed as a total for all lanes in lane group on the intersection approach ( $\mathrm{veh} / \mathrm{h})$;

$S_{0}$ - ideal saturation flow rate per lane $(\mathrm{pc} / \mathrm{h} / \mathrm{ln})$;

$\Pi f_{i}$ - product of correction factors affecting the saturation flow.

Depending on the parameters that affect the real saturation flow, the calculation methods that are used to determine it can be divided into three groups (Fig. 1):

- classic, the model for calculating saturation flows was first proposed by F. Webster [4], the method described by him is generally accepted all over the world, including in Ukraine;

- classic adjusted, which differs from the classical method of determining the ideal saturation flows of the roadway;

- method recommended by the American "Highway Capacity Manual" (HCM) [20]. This technique is used in many countries around the world.

The methods that are used in the calculation include both similar and different parameters. 


\begin{tabular}{|c|c|}
\hline \multicolumn{2}{|c|}{$\begin{array}{l}\text { Methods of determining saturation flows of the } \\
\text { roadway }\end{array}$} \\
\hline \multicolumn{2}{|c|}{$\begin{array}{c}\text { The following parameters are taken into } \\
\text { account }\end{array}$} \\
\hline Classic & Recommended by the Highway \\
\hline - width of the roadway at the & $\begin{array}{l}\text { Capacity Manual } \\
\text { (HCM 2000), USA }\end{array}$ \\
\hline $\begin{array}{l}\text { - distribution of traftic flows } \\
\text { in directions from one lane } \\
\text { (group of lanes); } \\
\text { - turning radius; } \\
\text { - grade. }\end{array}$ & $\begin{array}{l}\text { - number of lanes; } \\
\text { - lane width; } \\
\text { - distribution of traffic flows in } \\
\text { directions from one lane (group } \\
\text { of lanes): }\end{array}$ \\
\hline & - grade; \\
\hline Classic adjusted & - the existence of a parking lane \\
\hline $\begin{array}{l}\text { - number of lanes; } \\
\text { - lane width; } \\
\text { - distribution of traffic flows } \\
\text { in directions from one lane } \\
\text { (group of lanes); } \\
\text { - grade; } \\
\text { - turning radius } \\
\end{array}$ & $\begin{array}{l}\text { lane group; } \\
\text { - availability of bus (trolleybus) } \\
\text { stops and number of stops per } \\
\text { hour; } \\
\text { - area type; } \\
\text { - uneven loading of lanes } \\
\text { - obstacles created by pedestrians } \\
\text { to cars turning right or left }\end{array}$ \\
\hline
\end{tabular}

Fig. 1. Methods of determining saturation flows

The classic method of determining saturation flows was suggested by F. Webster in 1958 and has the following algorithm for calculating saturation flows [22, 23].

The ideal saturation flow is determined depending on the width of the carriageway by the formula (7).

The real saturation flow by the classical method is determined by the formula:

$$
S=S_{0} \cdot f_{i} \cdot f_{R} \cdot f_{n},
$$

where $f_{i}$-adjustment factor for approach grade;

$f_{R}$ - adjustment factor, taking into account the vehicles radius of turn from individual lanes or lanes groups;

$f_{n}$ - adjustment factor, taking into account the distribution of traffic in the directions of a single lane or group of lanes.

The calculated value of the saturation flow varies depending on the value of the approach grade: each percentage of the grade on the rise reduces its value, and on the descent increases by $3 \%$ :

$$
f_{g}=1 \mp \frac{3 \cdot g}{1000}
$$

where $g$ - approach grade, $\%$.

Right and left turning flows move in separate lanes (or groups of lanes), saturation flows are calculated depending on the turning radius $R$ :

- for single-row traffic:

$$
f_{R}=\frac{1}{1+\frac{1.525}{R}}
$$

- for two-row traffic:

$$
f_{R}=\frac{1.67}{1+\frac{1.525}{R}} \text {. }
$$

If at the intersection it is impossible to allocate separate lanes for each direction of movement, then due to mutual obstacles of cars moving from one lane in different directions, the saturation flow decreases. This effect can be neglected when the share of the returning flows less than $10 \%$. At higher intensity of the returning vehicles, all flow is reduced to one conditional by means of reduction coefficients equal for direct movement 1.0, turn to the left 1.75, turn to the right 1.25 :

$$
f_{n}=\frac{100}{a+1.75 \cdot b+1.25 \cdot c},
$$

where $a, b$ and $c$-the percentages of intensity, respectively, for the direct movement, for left turn and for right turn from the total amount on the approach to the intersection, \%.

The classical method allows to set the value of the ideal saturation flow for the lane of any width using the data [22, 23]. However, for a road with several lanes, the calculation according to the formula (7) gives the average values of saturation flows, regardless of the number of lanes and their width. Therefore, in the adjusted classical method for the roadway width of $5.4 \mathrm{~m}$, the number of lanes and their width is preset, and the ideal saturation flow of road is calculated by the formula:

$$
S_{0}=S_{0 L} \cdot n,
$$

where $S_{O L}$ - ideal lane saturation flow, veh $/ \mathrm{h}$, determined according to table. 2 ;

$n$ - number of lanes.

Further calculation of real saturation flows is performed by formula (9).

The Transport Research Council of the National Academies of Sciences in the United States has been conducting capacity and level of service studies for various highways for several decades. The results of these studies are published in the "Highway Capacity Manual" (HCM) [20]. The manual contains concepts, 
guidelines and computational procedures for calculating road capacity, including signalized intersections.

HCM 2000 recommends taking into account a much larger number of parameters that affect it than in the classical method when calculating the saturation flow, and adjust the value of the ideal saturation flow taking into account the real traffic conditions at the particular intersection according to the following formula:

$$
\begin{gathered}
S=S_{0} \cdot n \cdot f_{w} \cdot f_{g} \cdot f_{H V} \cdot f_{p} \cdot f_{b b} \cdot f_{a} \cdot f_{L U}, \\
\cdot f_{L T} \cdot f_{R T} \cdot f_{L p b} \cdot f_{R p b},
\end{gathered}
$$

where $s_{o}$ - base saturation flow rate per lane $(\mathrm{pc} / \mathrm{h} / \mathrm{ln})$;

$n$ - number of lanes in lane group;

$f_{w}$ - adjustment factor for lane width;

$f_{g}-$ adjustment factor for approach grade;

$f_{H V}$ - adjustment factor for heavy vehicles in traffic stream;

$f_{\mathrm{p}}$ - adjustment factor for existence of a parking lane and parking activity adjacent to lane group;

$f_{\mathrm{bb}}-$ adjustment factor for blocking effect of local buses that stop within intersection area;

$f_{a}$ - adjustment factor for area type;

$f_{L U}$ - adjustment factor for lane utiliza-

tion;

$f_{L T}$ - adjustment factor for left turns in lane group;

$f_{R T}-$ adjustment factor for right turns in lane group;

$f_{L p b}-$ pedestrian adjustment factor for leftturn movements;

$f_{R p b}$ - pedestrian-bicycle adjustment factor for right-turn movements.

Thus, the analysis allowed us to establish three main methods for determining saturation flows.

The classical method of determining saturation flows does not take into account the lane width and a number of parameters that affect the real saturation flow.

The adjusted classical method takes into account the lane width, but when determining the real saturation flows does not differ from the classical one.

The method recommended by HCM allows to consider a considerable quantity of the parameters influencing a real saturation flow, but differs in labour-intensive of calculations.

Recommendations for using of these techniques can be made after their comparative analysis.

\section{Input parameters for analysis}

Theoretical calculations and world experience suggest that with flow of only cars and speed of $50 \mathrm{~km} / \mathrm{h}$ the width of lanes that depends on their quantity in this direction and location, should be in the range of $2.75-3.5 \mathrm{~m}$. If there are vehicles $2.5 \mathrm{~m}$ wide in the traffic flow, then the width of the lane should be in the range of 3.5$4.0 \mathrm{~m}$.

Consider other parameters that affect the real saturation flow per lane:

- approach grade. According to DBN B.2.3-5:2018 [24] on the highway and roads of all groups of settlements of Ukraine the approach grade should not exceed $6 \%$, on streets and roads of local significance $-8 \%$. In further calculations, the value of the approach grade will be taken within $-8 \%<i<+8 \%$ ("minus" means that the flow on the approach to the intersection moves downhill, "plus" - the flow moves uphill);

- heavy vehicles in traffic flow. The share of heavy vehicles on the urban road network of cities does not exceed $10 \%$. This value will be considered as a limit in further calculations;

- existence of a parking lane and parking activity adjacent to lane group. The impact of street parking on the approach to the intersection, or behind it, is due to obstacles created by cars parked in or out of the parking lot. The maximum number of maneuvers is 180 maneuvers/h [20];

- blocking effect of local buses that stop within intersection area. The effect of stops depends on the number of routes and the interval of traffic on each of them. During calculation the maximum number of stops is $250 \mathrm{stops} / \mathrm{h}$;

- area type. According to the recommendations of the HCM for the central districts of the city we accept $f_{\mathrm{a}}=0.9$, in other districts $f_{\mathrm{a}}=1$;

- uneven loading of groups of lanes. HCM method recommends to take the difference in lane loading equal to $5 \%$, or to conduct the nature of the survey;

- turn flows. During the left-turn flow movement from the selected lane, the saturation flow decreases due to the decrease in the vehicles speed on the turn compared to the movement straight. The value of the radius of turn of the left-hand flows is taken in the range of 15$25 \mathrm{~m}$.

In case of the left turn from the distribution lane without conflict with the oncoming, the saturation flow of the distribution lane will depend on the share of the turning flow.

In case of the left turn from the distribution 
lane with a conflict with the oncoming flow, the value of the saturation flow will also be affected by its intensity. In the calculations we take the intensity of the oncoming flow from $100 \mathrm{veh} / \mathrm{h}$ up to $700 \mathrm{veh} / \mathrm{h}$.

The parameters that affect the saturation flows with right turn are the same as when vehicle turns to the left except for the conflict with the oncoming flow. Limits of initial parameters at calculations of influence of right-turning flows we accept the following: radius of turn from $5 \mathrm{~m}$ to $15 \mathrm{~m}$, share of a turning stream from $10 \%$ to $80 \%$;

- pedestrian flows. Turning flows that conflict with pedestrians, as in the previous case, can move from the designated lane and from the distribution. General parameters that affect the saturation flow turns right and left are: the intensity of pedestrian flows, which in the calculations we take from $250 \mathrm{ped} / \mathrm{h}$ up to $1000 \mathrm{ped} / \mathrm{h}$ and the share of return flows, which in the calculations we take from $25 \%$ to $75 \%$. In addition, when turning left, we should take into account the intensity of the oncoming flow in the range from $200 \mathrm{veh} / \mathrm{h}$ up to $600 \mathrm{veh} / \mathrm{h}$.

\section{Comparative analysis of the definition of the ideal saturation flows}

Determination of saturation flows of one lane by the classical method was done in accordance with the values given in tables 1 and 2 using interpolation.

The calculation of ideal saturation flows according to the method proposed in the "Highway Capacity Manual" (HCM) [20] was performed according to the formula:

$$
S_{0 L}=S_{0} \cdot f_{w},
$$

having in mind that the base value of the saturation flow $S_{0}$ is $1900 \mathrm{veh} / \mathrm{h}$ for a $3.6 \mathrm{~m}$ lane wide. The lane width coefficient $f_{w}$ was calculated by the formula:

$$
f_{w}=1+\frac{b-3.6}{9}
$$

where $b$-lane width, $\mathrm{m}$.

The value of the lane width can vary from $2.4 \mathrm{~m}$ to $4.8 \mathrm{~m}$. The $4.8 \mathrm{~m}$ wide lane should be considered as two narrow lanes.

The difference in calculating the ideal value of saturation flow according to the classical technique relative to the HCM technique is shown in Fig. 2.
According the DBN B.2.3-5:2018, the maximum value of the traffic lane width is $3.75 \mathrm{~m}$. At the same time the deviation of calculation does not exceed $3.5 \%$ both according to Yu. A. Kremenets and E. M. Lobanov's data. Also, the maximum width of the lane, even on the main roads of cities will not exceed $3.5 \mathrm{~m}$ in this case, the deviation in the calculations according to E. M. Lobanov will not exceed $2 \%$.

The value of the ideal saturation flow of the lane with a width of 2.5 to $3.5 \mathrm{~m}$ with sufficient accuracy can be determined both by the classical method according to E. M. Lobanov and by the method of HCM. In further comparative analysis we will use the data of E. M. Lobanov.

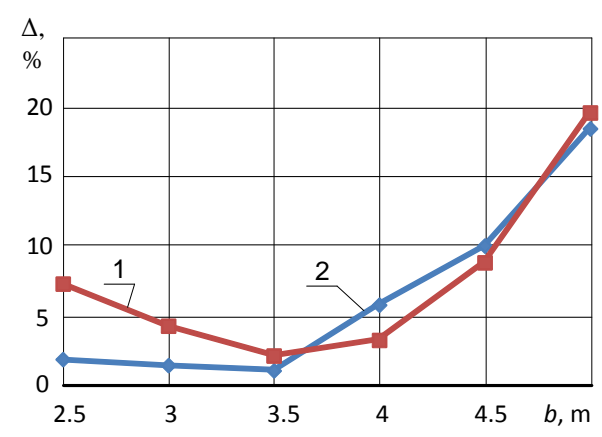

Fig. 2. Percentage deviation of the calculation data of the saturation flow of one lane according to the classical method in relation to the method of HCM: 1 - calculation according to the data of Yu. A. Kremenets; 2 - calculation according to E. M. Lobanov

For a group of lanes in the classical method, the ideal saturation flows are calculated regardless of the number of lanes by formula (7). The adjusted classical method and the HCM method suppose preliminary definition of number of lanes on the road with several lanes and calculation of an ideal saturation flow by the formula:

$$
S_{0 L}=S_{0} \cdot f_{w} \cdot n,
$$

where $n$ - the number of lanes for traffic in this direction.

Figure 3 shows the values of ideal saturation flows calculated by different techniques.

According to the calculations, the values of the ideal saturation flow, determined by the classical and adjusted classical methods, coincide well enough if the width of the lanes exceeds $3.5 \mathrm{~m}$. With a smaller width of lanes, there is a good coincidence of the calculated values obtained by the classical adjusted method and 
the method of HCM - the deviation between them does not exceed $2 \%$.

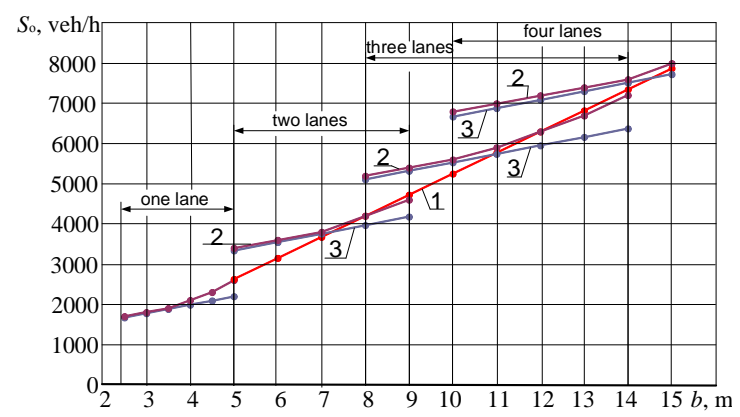

Fig. 3. The value of ideal saturation flows depending on the width of the road, calculated by different methods: 1 - calculations by the classical method; 2 - calculations according to the classical adjusted method; 3 - calculations according to the method of HCM

At the same time, the discrepancy between the values of ideal saturation flows determined by the classical method and the HCM method is much larger, and if the width of lanes is $2.5 \mathrm{~m}$ reaches $20 \%$. If the lanes width exceeds $3.5 \mathrm{~m}$, both the classical method and the classical adjusted give inflated values of ideal saturation flows and if the width of lanes is $4.5 \mathrm{~m}$, the excess relatively to the method of HCM is $10-$ $15 \%$.

Calculations of ideal saturation flows by all methods give a good coincidence of data if the width of lanes in the group is 3.5-3.75 m. Having in mind the global trend to reduce the width of lanes in cities, which is also declared in DBN B.2.3-5:2018 "Streets and roads of settlements" [24], calculations of ideal saturation flows of groups of lanes, the width of which does not exceed $3.5 \mathrm{~m}$, should be done according to the adjusted classical method, or the method of HCM.

The values of the coefficient that takes into account the approach grade $f_{g}$ by the classical method were calculated according to formula (10), by the method of HCM - according to the formula:

$$
f_{g}=1-\frac{g}{200}
$$

where $g$ - approach grade, \%o.

At approach grade of $40 \%$, which are quite common in urban conditions, the deviation exceeds $10 \%$ (Fig. 4).

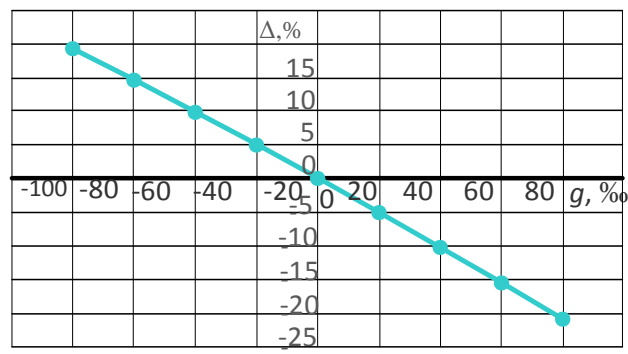

Fig. 4. Deviation of the coefficient values which takes into account the influence of the approach grade, calculated by the classical method relative to the values obtained by the method of HCM

Considering that studies of the effect of approach grade on the saturation flow, published in [20] were conducted much later than studies that gave us calculation formula (10) [22, 23]. Calculations, in our opinion, should be performed by the method of HCM.

The classical method does not take into account the presence of heavy vehicles in traffic flow, believing that the saturation flows, both ideal and real, are determined in the given cars per hour. However, the reduction factors [23, 25] take into account the overall dimensions of vehicles, but do not take into account their dynamic qualities. The HCM methodology recommends additionally take into account these parameters and calculate the impact of heavy vehicles on real saturation flows.

According to the calculation, each percentage of heavy vehicles in the traffic flow will reduce the real saturation flow by about $1 \%$. Thus, in our opinion, if the number of heavy vehicles exceeds $5 \%$, their impact on the real saturation flow should be taken into account.

When calculating the saturation flows, the share of the roadway width occupied by cars parked near the sidewalks is not taken into account. Therefore, the classical method neglects the influence of parking. However, cars maneuvering for the purpose of entering or exiting a street car park create obstacles to the flow moving along a group of lanes along which street car parks are permitted. In the HCM method, based on the study of delays created by cars parked on the roadway at a distance closer than $75 \mathrm{~m}$ from intersections, the value of the coefficient depends on the number of parking spaces per hour, as well as the total number of lanes on the roadway:

$$
f_{p}=\frac{n-0.1-\frac{18 \cdot N_{m}}{3600}}{n},
$$


where $n$ - number of lanes in lane group on the approach of intersection;

$N_{m}$ - number of parking, maneuvers/h.

On a road with two lanes, one of which is occupied by a parking lot, already at 100 maneuvers per hour the saturation flow in the adjacent lane is reduced by $30 \%$. Even on a road with four lanes, on three intended for traffic, the real saturation flow is reduced by $15 \%$ with the same number of maneuvers. It is necessary to take into account the influence of street parking on the flow of saturation, if they are near the intersection.

The classical method does not take into account the effect of the presence of public transport stops near the crossroads on the saturation flow. However, the presence of stops, as well as parking at a distance of less than $75 \mathrm{~m}$ on both sides of the intersection, according to the HCM significantly affect the real saturation flow and the impact factor is calculated:

$$
f_{b b}=\frac{n-\frac{14.4 \cdot n_{b}}{3600}}{n},
$$

where $n_{b}$ - number of buses stopping/h.

If the number of stops per hour on two lanes road is equal to 100 , the coefficient $f_{b b}=0.8$ and the saturation flow decreases by $20 \%$. On a road with four lanes $f_{b b}=0.9$ and the saturation flow decreases by $10 \%$.

Considering that in the cities of Ukraine bus and trolleybus stops are located in the immediate vicinity of the intersection, their impact on the saturation flow should be taken into account.

The HCM method, in contrast to the classical one, recommends to reduce the estimated saturation flow by $10 \%$ for the central, historical and business districts of cities, thus additionally taking into account the set of narrow streets, small turning radii, large number of pedestrians and others.

The need to take this factor into account depends on the historical and transport planning of the city and in each case is assessed separately.

If there are two or more lanes for traffic in one direction, the HCM method recommends reducing the value of the total saturation flow of a lanes group by $5 \%$ due to the uneven distribution of the number of vehicles in the lanes.

The following should be noted:

- in the areas between intersections, the uneven distribution of the number of vehicles in the lanes may exceed $5 \%$, but on the approach to the intersection, as evidenced by studies, their number is equalized;

- saturation flows are calculated for a fully saturated phase and a small difference in the number of cars waiting in line cannot affect their value.

Given the above, we believe that when calculating the saturation flows, taking into account the uneven distribution of vehicles in the lanes is impractical.

When turning flows (left-turning) move from one selected lane without conflict with the opposite flow, the classical method assumes that the saturation flow depends on the turn radius of the car and recommends calculating the impact factor $f_{T}$ for single-row motion according to (11). The HCM technique considers that the main factor influencing the saturation flows is the maneuver time, which depends on the turning radius and the speed of movement, which increases with increasing radius. Therefore, it is recommended to take the values of the coefficients of influence as a constant value: for leftturning flows $(R=15-25 \mathrm{~m}) f_{L T}=0.95$; for rightturning $(R=5-15 \mathrm{~m}) f_{R T}=0.85$. The difference between the values of the coefficients of influence of the turn flows from the selected lane on the saturation flows, determined by the classical method, relative to the method of HCM are shown in Fig. 5.

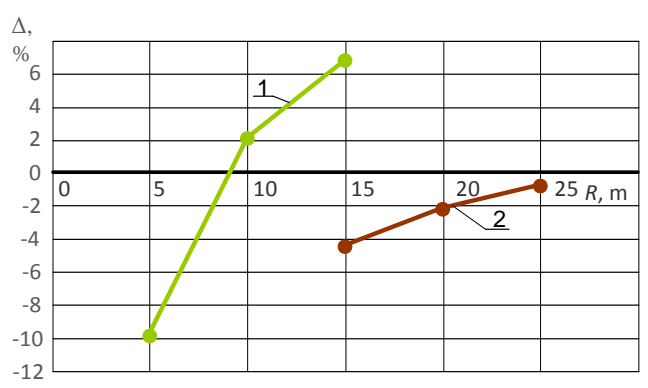

Fig. 5. Percent discrepancy of values of coefficients of influence of turning flows from the dedicated lane on saturation flows, defined by a classical technique, concerning the HCM technique: 1 - turns to the right; 2 - turns to the left

When turning to the right, the values of the coefficients coincide well with a turning radius of $10 \mathrm{~m}$, when turning to the left - with turning radii of more than $20 \mathrm{~m}$. Such radii are the most typical for urban conditions. However, to provide recommendations on which technique should be used for other values of the turning radius, it is necessary to conduct additional research. The same is observed when we have right-turning traffic flows. 
If the left-turning traffic flow is carried out from the distribution lane without conflict with the oncoming direct flow, then according to the classical method, the coefficient taking into account the influence of turns flows from the distribution lane $f_{L T}$ on the real saturation flow is calculated by formula (13), which in case of movement in this lane directly and to the left takes the form:

$$
f_{T}=\frac{100}{a+1.75 \cdot b},
$$

where $a$ and $b$ - the percentages of intensity, respectively, the direct direction of movement and those turning to the left of the lane, $\%$.

The HCM method recommends to calculate the coefficient of influence of the left-turning flow moving from the distribution lane without conflict with the oncoming flow by the formula:

$$
f_{L T}=\frac{1}{1.0+0.05 \cdot P_{L T}},
$$

where $P_{L T}-$ proportion of left turns in lane group.

The influence of left-turning flows moving from the distribution lane without conflict with the oncoming flow on the coefficient of reduction of the ideal saturation flow by the HCM method is much smaller than by the classical one (Fig. 6).

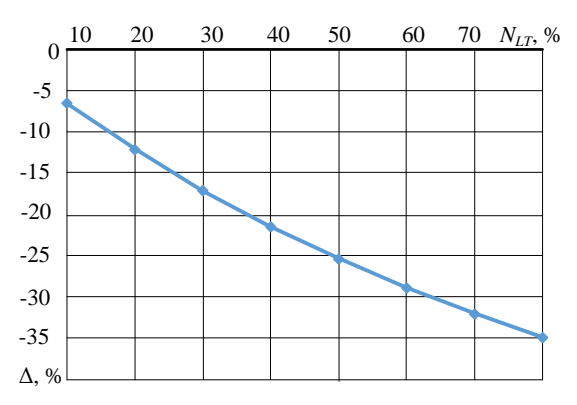

Fig. 6. Percentage discrepancy between the values of the coefficients of influence of the turning flows from the distribution lane on the saturation flows, determined by the classical method, relative to the method of HCM

According to the classical method, the coefficient that takes into account the influence of turning flows from the distribution lane on the real saturation flow is calculated by the formula (20).

Analysis of formula (20) shows that it does not take into account the presence of traffic on the oncoming lanes and their intensity.

According to the research presented in [20], the intensity of movement in the oncoming group of lanes of the main direction significantly affects the real saturation flow of the distribution lane (group of lanes).

The HCM method recommends determining the real saturation flow taking into account not only the share of left-turn flow, but also the intensity of the oncoming flow, the number of lanes in the group from which the left turn is done and the number of lanes in the opposite direction. The calculation procedure is quite complex and to simplify it in [26] nomograms are given to determine the coefficient of influence of left-turn flows from the distribution lane and the conflict with the oncoming flow of $f_{L T C}$ depending on the factors that were mentioned above. As an example, we calculated the values of the coefficient of influence of the left-turn flows using the following initial data: the number of distribution lanes with the left turn - 1 , the number of lanes in the opposite direction 1 , the share of left-turn flow varies from $25 \%$ to $95 \%$, the intensity of the opposite conflicting flow varies from 100 to $700 \mathrm{veh} / \mathrm{h}$. (Fig. 7).

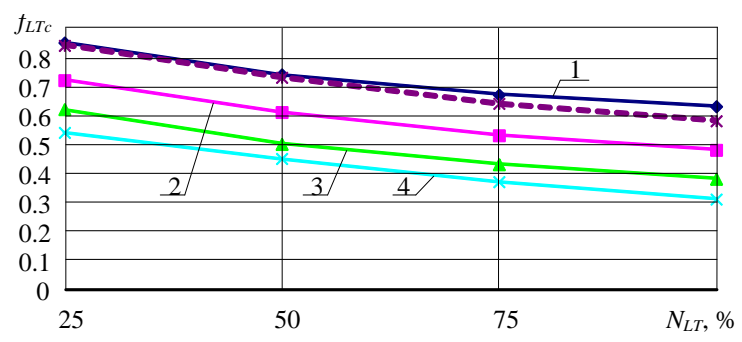

Fig. 7. The value of the influence coefficients of the share of the left-turn flow from the distribution lane on the saturation flow: solid lines - calculations by the method of HCM: 1 - at the intensity of the oncoming flow 100 $\mathrm{veh} / \mathrm{h} ; 2-300 \mathrm{veh} / \mathrm{h} ; 3-500 \mathrm{veh} / \mathrm{h} ; 4-700$ $\mathrm{veh} / \mathrm{h}$; dashed line - calculation according to the classical method

Data on the values of the influence coefficient of the share of the left-turn flow from the distribution lane, calculated by the classical method and the method of HCM coincide quite well with a small intensity of the oncoming flow (about $100 \mathrm{veh} / \mathrm{h}$ ). As the intensity of the oncoming conflicting flow increases, the discrepancy between the values of the coefficients increases.

It should be noted that the calculations according to the method of HCM are valid at the total traffic intensity along the distribution lane, 
which does not exceed $480 \mathrm{veh} / \mathrm{h}$. At higher values of the total intensity and the share of leftturn flows $25 \%$, the number of cars that are making turn will exceed $120 \mathrm{veh} / \mathrm{h}$, and in this case, according to current specifications [22] it is necessary to define a separate lane for leftturn flows. Additional studies must be done to estimate the impact of left-turn flows, which are less than $25 \%$.

According to the classical method, the coefficient that takes into account the influence of turning flows from the distribution lane $f_{d, r}$ on the real saturation flow is calculated by formula (13), which is for the case of movement in this lane directly and to the right takes the form:

$$
f_{d, r}=\frac{100}{a+1.25 \cdot c},
$$

where $c$ - the percentage of the total flow intensity that turns to the right from this lane, $\%$.

The HCM method recommends to determine the saturation flow reduction coefficient of the distribution lane if there are of right-turn flows according to the formula:

$$
f_{R T}=1.0-0.15 \cdot P_{R T},
$$

where $P_{R T}$ - proportion of right turns in lane group.

According to the HCM method, this effect is smaller than according to the classical one, which can be explained by the better dynamic qualities and stability of modern cars. This discrepancy increases with increasing relative number of cars turning right, but even their share is $70 \%$, it does not exceed $5 \%$ (Fig. 8).

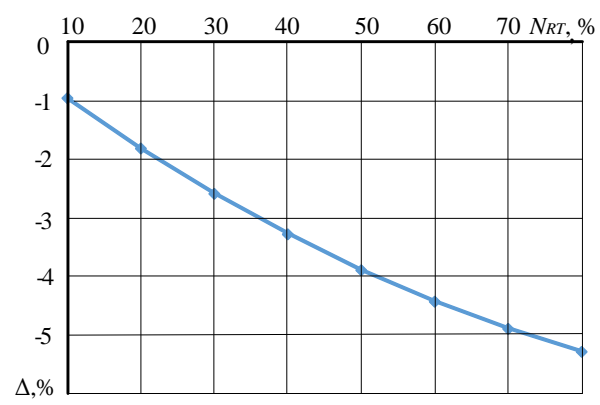

Fig. 8. Percentage discrepancy of the influence coefficient of the right-turn flow on the saturation flows of the distribution lane, determined by the classical method, relative to the method of HCM, depending on the share of the turn flow
The classical technique does not take into account the obstacles created by pedestrians to the cars turning left or right.

Many years of research in the field of transport in the United States have established the effect of this parameter on the saturation flow for different traffic management schemes at a signalized intersection [20].

The results of these studies and the algorithm for determining the impact coefficients of pedestrian flows by a special procedure using nomograms are also published in ODM 218.2.020-2012 [26].

The technique allows to determine the value of the influence coefficient of pedestrian flows with intensity from $100 \mathrm{ped} / \mathrm{h}$ up to $1000 \mathrm{ped} / \mathrm{h}$ on the saturation flow in the following cases:

- the movement of the left-turn flow from the selected lane without conflict with the oncoming flow;

- movement of the left-turn flow from the distribution lane without conflict with the oncoming flow;

- the movement of the left-turn flow, the share of which is from $25 \%$ to $75 \%$, from the distribution lane with a conflict with the opposite flow intensity from 0 to $1000 \mathrm{veh} / \mathrm{h}$.

The organization of traffic on the signalized intersection, when the left-turn flow returns from the selected lane without conflict with the oncoming and at the same time conflicts with the pedestrian, the edge is rare (for example, in one-way traffic). However, the influence of pedestrian flows on the value of $f_{L P e d}$ is better illustrated in this case (Fig. 9). According to the given data, even at an intensity of pedestrian traffic of $250 \mathrm{ped} / \mathrm{h}$ the saturation flow is reduced by almost half, and at values close to $1000 \mathrm{ped} / \mathrm{h}$ is only $20 \%$ of the ideal.

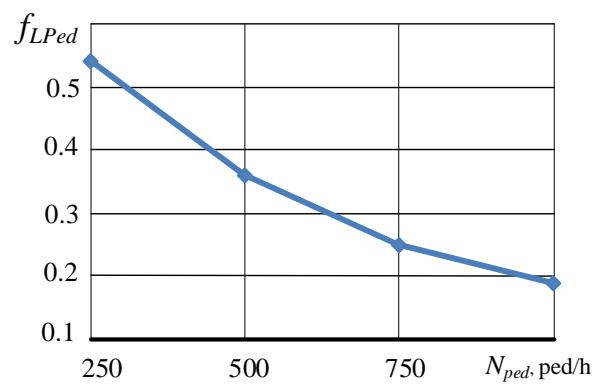

Fig. 9. Graph of the dependence of the coefficient $f_{L P e d}$ on the pedestrian flow intensity in the case when the left-turn flow turns from the devoted lane without conflict with the oncoming flow 
The organization of the left-turn flow movement at the signalized intersection from the distribution lane without conflict with the opposite, oncoming flow takes place in some cases, for example, in one-way traffic. With increasing intensity of pedestrian traffic, as well as the share of left-turning flow, the value of the coefficient $f_{L P e d}$ decreases (Fig. 10).

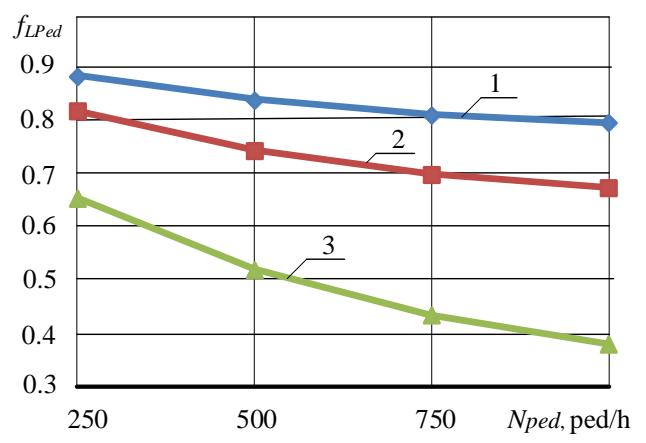

Fig. 10. Graph of the dependence of the coefficient $f_{L P e d}$ from the pedestrian flow intensity in the case when the left-turn flow turns from the distribution lane without conflict with the oncoming flow. The share of left-turn flow: $1-25 \% ; 2-50 \% ; 3-75 \%$

Left-turn traffic from the distribution lane is usually done in conflict with the oncoming flow of vehicles. In this case, the saturation flow is simultaneously affected by both: the intensity of the oncoming flow and the pedestrian flow. In this case, the greater the intensity of the oncoming flow and its effect on the saturation flow, the smaller the effect of pedestrian flow (Fig. 11). Increasing the share of left-turn flow increases the influence of pedestrian flow on the saturation flow.

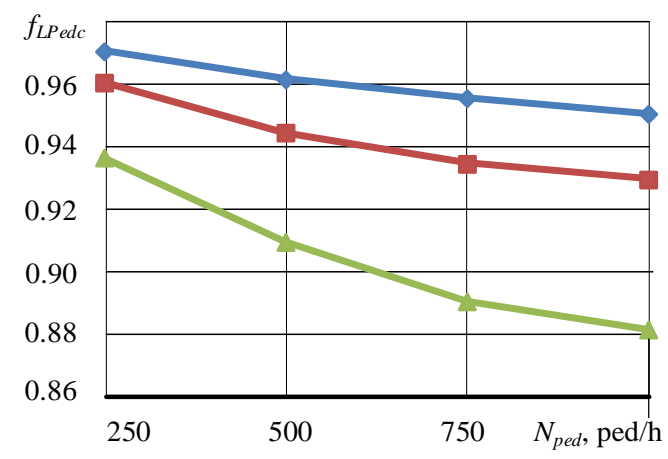

Fig. 11. Dependences of the coefficient fLPedc from the intensity of pedestrian flow with a share of left-turn flow of $25 \%$ with a conflict with the oncoming flow. Intensity of the oncoming flow: $1-600 \mathrm{veh} / \mathrm{h} ; 2-400 \mathrm{veh} / \mathrm{h}$; $3-200 \mathrm{veh} / \mathrm{h}$
If the turn to the right is done from the distribution lane, the coefficient taking into account the influence of pedestrian flows also depends on the share of the right-turn flow on the total on the lane, or a group of lanes (Fig. 12).

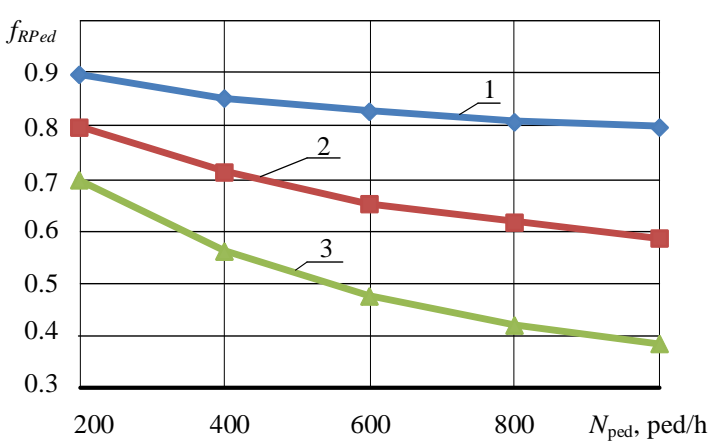

Fig. 12. Dependences of the coefficient fppish on the intensity of pedestrian flow with the share of right-turn flow 25, 50 and $75 \%$ of the total on the lane. The share of right-turn flow: $1-25 \% ; 2-50 \% ; 3-75 \%$

In case of right turn from the devoted lane, the value of the coefficient that takes into account the obstacles created by pedestrians depends only from the intensity of pedestrian flow. The reduction coefficients of the saturation flow in this case are the same as in the case of leftturn flow from the devoted lane (Fig. 9).

\section{Conclusions}

The analysis identified three main methods for determining saturation flows: classical, classical adjusted, and the method recommended in the Highway Capacity Manual (HCM). The classical method of determining ideal saturation flows does not take into account the lane width and a number of parameters that affect the real saturation flow. The adjusted classical method takes into account the lane width, but in case of determining the real saturation flows does not differ from the classical one. The method recommended by the HCM allows to take into account a significant number of parameters that affect the real saturation flow.

Determination of ideal saturation flows of one lane with a width of 2.5 to $4 \mathrm{~m}$ can be done both by the classical method (according to E. M. Lobanov) and by the method of HCM.

Determination of ideal saturation flows of groups of lanes should be done according to the classical adjusted method, or according to the method of HCM. Calculations by the classical method give the same results only if the width of the lanes is $3.75 \mathrm{~m}$. At smaller values of the 
width of the lanes, the deviation in the calculations can reach $20 \%$.

The most significant factors in determining the real saturation flow are the intensity of the oncoming flow and pedestrian flows, which according to the classical method are not taken into account.

Quantitative values of influence coefficients in determining the real saturation flows require additional research and refinement for domestic conditions.

\section{References}

1. Кременец Ю. А., Печерский М. П. Инженерные расчеты в регулировании движением. Москва, 1977. 110 с.

2. Кременец Ю. А., Печерский М. П. Применение технических средств для регулирования дорожным движением. Москва, 1974. 173 с.

3. Врубель Ю. А. О потоке насыщения. Минск, $1988.7 \mathrm{c}$.

4. Webster F. V., Cobbe B. M. Traffic Signals. Road Research Technical Paper. 1966. No. 56. P. 111.

5. Branston D., Van Zuylen H. J. The estimation of saturation flow, effective green time and passenger car equivalents at traffic signals by multiple liner regression. Transportation research. 1987. Vol. 12. P. 47-53.

6. Stokes R. W. Comparison of saturation flow rates at signalized intersections. ITE Journal. 1988. Vol. 15. No. 11. P. 15-20.

7. Wardrop J. G. Some Theoretical aspects of Road Traffic Research. Proceedings of the Institute of Civil Engineers 1952. Part II Vol. 1. P. 325-378.

8. Webster F. V. Traffic signal Settings. Road Research Technical Paper. 1958. No. 39. P.44-45.

9. Highway Capacity Manual. Transportation Research Board, Washington, DC, 1950. 1134 p.

10. Greenshields B. D., Schapiro D., Ericksen E. L. Traffic Performance at Urban Street Intersections. Technical Report. No.1. Yale Bureau of Highway Traffic, 1947. 174 p.

11. Bartle R. M., Skoro V., Gerlough D. L. Starting Delay and Time Spacing of Vehicles Entering Signalized Intersections. Highway Research Board Bulletin. 1956. No.112. P. 33-41.

12. Capelle D. G., Pinnell C. Capacity Study of Signalized Diamond Interchanges. Highway Research Board Bulletin. No. 291. 1961. P. 1-25.

13. Assmus W. E. Operational Performance of Exclusive Double Left Turn Lanes. Evanston, IL: Northwestern University. 1970. P. 57.

14. Carstens R. L. Some Traffic Parameters at Signalized Intersections. Traffic Engineering. 1971. Vol. 41. No. 11. P. 33-36.

15. Berry D. J. Capacity and Quality of Service of Arterial Street Intersections. Research Report 301. College Station, Texas. 1974. 58 p.

16. King G. F., Wilkinson M. Relationship of Signal Design to Discharge Headway, Approach Capacity, and Delay». Transportation Research Record.
1976. No. 615. P. 37-44.

17. Kunzman W. Another Look at Signalized Intersection Capacity. ITE Journal. 1978. No. 8. P. 12-15.

18. Interim Materials on Highway Capacity. Transportation Research Board. Circular 212. 1980.

19. Левашев А. Г., Михайлов А. Ю., Головных И.М. Проектирование регулируемых пересечений. Иркутск, 2007. 208 с.

20. Highway Capacity Manual. Transportation Research Board, Washington, DC 2000. 1134 p.

21. Handbuch für die Bemessung von Straßenverkehrsanlagen (HBS 2001) Forschungsgesellschaft für Straßen- und Verkehrswesen, Köln, Januar 2002. 390 p.

22. Кременец Ю. А., Печерский М. П., Афанасьев Н. Б. Технические средства организации дорожного движения. Москва, 2005. 279 с.

23. Лобанов Е. М. Транспортная планировка городов. Москва, 1990. 240 с.

24. ДБН В.2.3-5:2018. Вулиці та дороги населених пунктів. Київ, 2018. 55 с.

25. Hall L. E., Powers R. D., Turner D. S., Brilon W., Hall J. W. Overview of cross section design elements. International Symposium on Highway Geometric Design Practises. Transportation Research Circular. 1998. URL: http://onlinepubs.trb.org/Onlinepubs/circulars/ec0 03/ch12.pdf (дата звернення: 21.04.2021)

26. ОДМ 218.2.020-2012. Методические рекомендации по оценке пропускной способности автомобильных дорог. Росавтодор. Москва, 2012. 144 c.

\section{References}

1. Kremenets Yu. A. Pecherskyi M. P. (1977) Ynzhenernye raschety $\mathrm{v}$ rehulyrovanyy dvyzhenyem. [Engineering calculations in traffic control] Moskva. [in Russian].

2. Kremenets Yu. A. Pecherskyi M. P. (1974) Prymenenye tekhnycheskykh sredstv dlia rehulyrovanyia dorozhnym dvyzhenyem. [Application of technical means for traffic regulation] Moskva. [in Russian].

3. Vrubel Yu. A. (1988) O Potoke Nasyshchenyia. [About the saturation flow] Mynsk. [in Russian].

4. Webster F. V., Cobbe B. M. (1966). Traffic Signals. Road Research Technical Paper. 56. 111.

5. Branston D., Van Zuylen H. J. (1987). The estimation of saturation flow, effective green time and passenger car equivalents at traffic signals by multiple liner regression. Transportation research. 12. 47-53.

6. Stokes R. W. (1988). Comparison of saturation flow rates at signalized intersections. ITE Journal. 15. 11. 15-20.

7. Wardrop J. G. (1952). Some Theoretical aspects of Road Traffic Research. Proceedings of the Institute of Civil Engineers. Part. II. 1. 325-378.

8. Webster F. V. (1958). Traffic signal Settings. Road Research Technical Paper. No. 39. P.44-45. 
9. Highway Capacity Manual. (HCM 1950). Transportation Research Board, Washington, DC.

10. Greenshields B. D., Schapiro D., Ericksen E. L. (1947). Traffic Performance at Urban Street Intersections. Technical Report. No.1. Yale Bureau of Highway Traffic.

11. Bartle R. M., Skoro V., Gerlough D. L. (1956). Starting Delay and Time Spacing of Vehicles Entering Signalized Intersections. Highway Research Board Bulletin. 112. 33-41.

12. Capelle D. G., Pinnell C. (1961). Capacity Study of Signalized Diamond Interchanges. Highway Research Board Bulletin. 291. 1-25.

13. Assmus W. E. (1970). Operational Performance of Exclusive Double Left Turn Lanes. Evanston, IL: Northwestern University.

14. Carstens R. L. (1971). Some Traffic Parameters at Signalized Intersections. Traffic Engineering. 41. 11. 33-36.

15. Berry D. J. (1974). Capacity and Quality of Service of Arterial Street Intersections. Research Report 30-1. College Station, Texas.

16. King G. F., Wilkinson M. (1976). Relationship of Signal Design to Discharge Headway, Approach Capacity, and Delay». Transportation Research Record. 615. 37-44.

17. Kunzman W. (1978). Another Look at Signalized Intersection Capacity. ITE Journal. 8. 12-15.

18. Interim Materials on Highway Capacity. (1980). Transportation Research Board. Circular 212.

19. Levashev A.H., Mykhailov A.Yu., Holovnykh Y.M. (2007). Proektyrovanye rehulyruemykh peresechenyi. [Design of adjustable intersections.] Yrkutsk. [in Russian].

20. Highway Capacity Manual. (HCM 2000). Transportation Research Board, Washington, DC.

21. Handbuch für die Bemessung von Straßenverkehrsanlagen (HBS 2001) Forschungsgesellschaft für Straßen- und Verkehrswesen, Köln.

22. Kremenets Yu. A., Pecherskyi M. P., Afanas-Ev N. B. (2005). Tekhnycheskye sredstva orhanyzatsyy dorozhnoho dvyzhenyia. [Technical means of traffic organization] Moskva. [in Russian].

23. Lobanov E. M. (1990). Transportnaia planyrovka horodov. [Transport planning of cities] Moskva. [in Russian].

24. DBN V.2.3-5:2018. (2018). Vulytsi ta dorohy naselenykh punktiv. [Streets and roads of settlements] Kyiv. [in Ukrainian].

25. Hall L. E., Powers R. D., Turner D. S., Brilon W., Hall J. W. (1998). Overview of cross section design elements. International Symposium on Highway Geometric Design Practises. Transportation Research Circular. URL: http://onlinepubs.trb.org/Onlinepubs/circulars/ec0 03/ch12.pdf (accessed: 21.04.2021).

26. ODM 218.2.020-2012. Metodycheskye RekoMendatsyy Po Otsenke Propusknoi Sposobno-Sty Avtomobylnykh Doroh. [ODM 218.2.020-2012. Methodical recommendations for assessing the capacity of highways] Rosavtodor. Moskva, 2012. [in Russian].
Semchenko Nataliia ${ }^{1}$, Ph.D., Assoc. Prof., Traffic Management and Road Safety Department, ssssssss@gmail.com, тел. +38 050-924-64-36, orcid: 0000-0002-5946-0402

Kholodova Olha ${ }^{1}$, Ph.D., Assoc. Prof., Traffic Management and Road Safety Department,

тел. +38 097 520-15-91,

olgakholodova2807@ukr.net,

orcid: 0000-0002-4217-0548

Buhaiova Maryna ${ }^{1}$, assistant, Traffic Management and Road Safety Department,

тел. +38 095 609-75-94, kazmar2383@gmail.com, orcid: 0000-0003-1889-9555

${ }^{1}$ Kharkov National Automobile and Highway University, 25, Yaroslava Mudrogo str., Kharkiv, 61002, Ukraine.

Порівняльний аналіз методів визначення потоків насичення

Анотація. Проблема. Пропускна спроможність регульованих перехресть визначається поняттям «потік насичення» - головною характеристикою в прочесі їхнього аналізу, проєктування та розрахунку. Робота присвячена вирішенню науковоприкладного завдання підвищення ефективності функиіонування регульованого перехрестя в одному рівні за рахунок вибору рачіонального для даних характеристик транспортних потоків, геометричних параметрів перехрестя та інфраструктури в його районі, методу визначення потоків насичення. Предметом дослідження $\epsilon$ вплив основних характеристик транспортного потоку, параметрів та інфраструктури перехрестя на величину потоку насичення. Мета. Метою роботи є аналіз впливу основних характеристик транспортного потоку, параметрів та інфраструктури перехрестя на величину потоку насичення. Методологія. Розрахунок режиму регулювання на перехресті основано на визначенні співвіднотення між інтенсивністю руху транспортних засобів на перехресті й величиною потоку насичення, значення якого змінюеться під впливом низки факторів. Аналітичний розрахунок значення потоку насичення базується на використанні коректуючих коефічіснтів, щзо враховують вплив ции факторів. Результати. У роботі проведений аналіз методів визначення потоків насичення; виконаний порівняльний аналіз визначення ідеальних потоків насичення за різними методами; здійснений порівняльний аналіз визначення коефіціснтів корекиії потоку насичення для параметрів, що впливають на нього; проведене оцінювання розбіжності в розрахунках коефіцієнтів корекиіі потоків насичення за різними методами; уточнений перелік коефіціснтів, які необхідно враховувати у визначенні їхнього впливу на потік насичення. Оригінальність. На відміну від класичного та інших підходів до визначення потоку насичення, метод, рекомендований американським «Керівництвом щзодо пропускної спроможності 
доріг», враховує більще параметрів впливу. Запропоновано в процесі розрахунку потоку насичення використання цьього методу, але з уточненим переліком коефіцієнтів, щзо необхідно враховувати в розрахунках. Практичне значення. Результати роботи можуть бути використані в практищі підвищення ефективності функціонування регульованих перехресть на ділянках вулично-дорожньої мережі міст, а також у подальших наукових дослідженнях із иієї тематики.

Ключові слова: потік насичення; регульоване перехрестя; вулично-дорожня мережа; метод.
Семченко Наталія Олександрівна ${ }^{1}$, к.т.н., доц. каф. організації та безпеки дорожнього руху, nat-semchenko@ukr.net, тел. +38 050-924-64-36, orcid: 0000-0002-5946-0402

Холодова Ольга Олександрівна ${ }^{1}$, к.т.н., доц. каф. організації та безпеки дорожнього руху, тел. +38 097 520-15-91,

olgakholodova2807@ukr.net,

orcid: 0000-0002-4217-0548

Бугайова Марина Олександрівна ${ }^{1}$, асист. каф. організації та безпеки дорожнього руху, тел. +38 095 609-75-94, kazmar2383@gmail.com, orcid: 0000-0003-1889-9555

${ }^{1}$ Харківський національний автомобільнодорожній університет, 61002, Україна, м. Харків, вул. Ярослава Мудрого, 25. 